\title{
The Composition of Benthic Vernal Diatoms Communities on the Lower Course of Bega River
}

\author{
Anca-Andreea MARIN ${ }^{1 *}$, Benoni LIXANDRU ${ }^{1}$, Adrian SINITEAN ${ }^{2}$, Milca PETROVICI ${ }^{2}$, Florica MORARIU ${ }^{1}$, \\ Dumitru POPESCU ${ }^{1}$, Valentin LATI ${ }^{1}$ \\ ${ }^{1}$ Banat University of Agricultural Sciences and Veterinary Medicine "King Michael I of Romania" from \\ Timisoara, Faculty of Animal Science and Biotechnology, \\ ${ }^{2}$ West University of Timişoara, Faculty of Chemistry Biology and Geography, Department of Chemistry- \\ Biology, Timişoara, Romania \\ *Corresponding author: marin.aandreea@yahoo.com
}

Bulletin USAMV series Agriculture 72(2)/2015

Print ISSN 1843-5246; Electronic ISSN 1843-5386

DOI 10.15835/buasvmcn-agr: 11730

\begin{abstract}
Diatoms are found in all aquatic habitats and species preferences can be used to make predictions about current and past conditions. Diatoms represents the multilateral and major importance in aquatic ecosystems as primary producers in the trophic networks, as producers of atmospheric $\mathrm{O}_{2}$ as active organism in the circuit of chemical elements in nature, or as participants in the natural process of self-purification of water. In April 2014, 20 quantitative phytobenthic and planktonic samples were collected from Bega River in Timisoara area. The present paper attempts to identified and bring new contributions regarding to the composition of benthic vernal diatoms communities on the lower course of Bega River. Until now it was identified 26 species, distributed in 9 families, 6 orders and two classes, of the benthic diatoms from the Bega River.
\end{abstract}

Keywords: Bega River water, diatom biomarkers, water quality.

\section{INTRODUCTION}

Diatoms represents the multilateral and major importance in aquatic ecosystems as primary producers in the trophic networks, as producers of atmospheric $\mathrm{O}_{2}$, as active organism in the circuit of chemical elements in nature, or as participants in the natural process of self-purification of water (Werner, 1977b).

Diatoms have been utilized to evaluate environmental and climatic changes in freshwater or brackish ecosystems (Denys \& Verbruggen, 1989; Ryu et al., 2008).

Organic indicators of water quality monitoring urbanized during the recent years have served as excellent tools in the area of water pollution studies. Among all the algae, fresh water diatoms are the most commonly used indicators of the conditions of water.

Diatoms are microscopic algae that live in both freshwater and marine environments. They have a siliceous shell, or frustule, consisting of two valves, that are generally preserved in sediments.

Diatoms are found in all aquatic habitats and species preferences can be used to make predictions about current and past conditions (Lowe, 1974).

Benthic diatoms represent some of the best bioindicators of algae because they are the base of food webs and are the first organisms that respond to changes in the environment (Lowe \& Pan, 1996), have short life cycles and therefore has a rapid response at the changes in the living environment factors, there are many species, widespread in different ecosystems and geographical areas so that lends itself to monitoring of large areas (Lavoie et al., 2009).

They are an important constituent of the biofouling community in the aquatic ecosystem.

The present paper attempts to identified and bring new contributions regarding to 
the composition of benthic vernal diatoms communities on the lower course of Bega River. A few studies were carried out along the whole river valley focusing on the composition of diatoms communities on the lower course of Bega River.

\section{MATERIAL AND METHODS}

In April 2014, 20 quantitative phytobenthic and planktonic samples were collected from Bega River in Timisoara area. The phytobenthic and planktonic samples were collected with planktonic net and stored in $4 \%$ formaldehyde (Lixandru, 2006, Marin et al, 2014, Péterfi et al, 2002, Petrovici, 2009).

Samples were collected from the upstream, middle and downstream of Timisoara city.

The collecting stations (S) were located as follows (figure 1):

S1 is located upstream of Timisoara city, near Ghiroda village, upstream of potable water treatment station.

S2 is located upstream of sewage water treatment station of Timisoara.

S3 is located near Sânmihaiu Roman village from Timis County and downstream of sewage water treatment station of Timisoara.

S4 is located near Otelec village, before the border line with Serbia Country.
The samples were collected by brushing the surfaces of substrata (3-5 rocks or respectively plant fragments, completely covered by water). Epipelic samples were collected by suction with a syringe. Each sample stored in recipients and preserved in $4 \%$ formaldehyde.

In laboratory the samples were subsequently treated with strong mineral acids (HNO3), and incinerated (for eight hours). The examination, taxonomic identification and the establishment of the floristic composition was done by using trinocular microscope (Olympus BX51), immersion objective (100x), and up-to-date identification books: Süsswasserflora von Mitteleuropa (Krammer and Lange-Bertalot - vol. 2/1, 1997; vol. 2/2, 2008; vol. 2/3, 2008; vol. 2/4, 2004; vol. $2 / 5,2000$ ), and Diatoms of Europe(coordinated by Lange-Bertalot - vol. 1, 2000; vol. 2, 2001; vol. 3, 2002; vol. 4, 2003). The light micrographs have been obtained with digital cameras adapted for the microscope (Olympus E330). The checklist of diatom flora was organized after the system presented in The Diatoms (Round et al., 2000).

\section{RESULTS AND DISCUSSION}

The taxonomic analysis of the benthic diatom flora from the Bega River until now, to

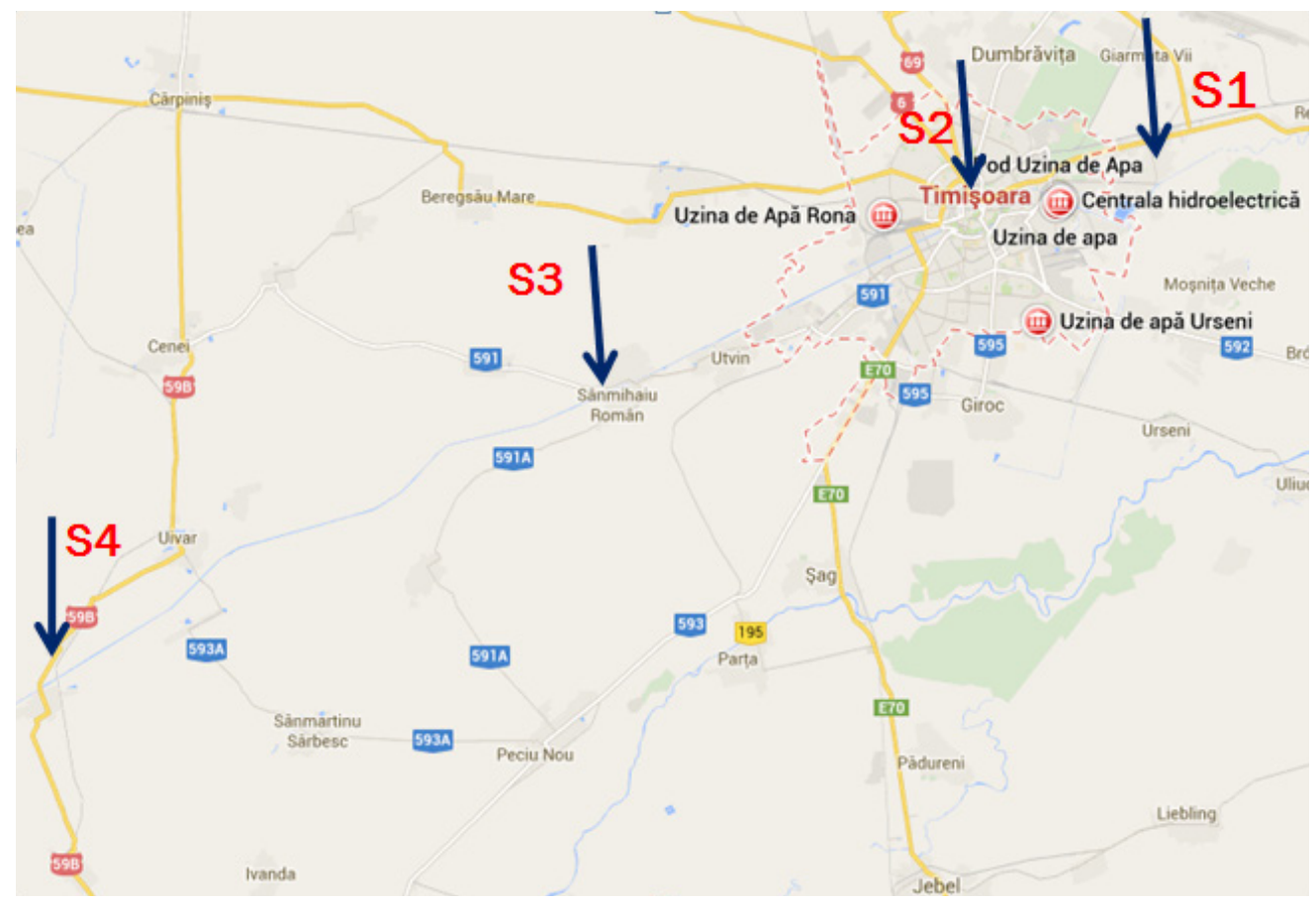

Fig. 1. The location of the sample collecting stations on Bega River water 
the identification of 26 species, distributed in 9 families, 6 orders and two classes:

Bacillariophyta

Fragilariophyceae Round

Fragilariophycidae Round

Fragilariales Silva

Fragilariaceae Greville

1. Diatoma moniliformis Kützing

2. Diatoma vulgaris Bory de St.-Vincent

3. Fragilaria capucina Desmazières

4. Fragilaria tenera (W. Smith) Lange-Bertalot

5. Synedra ulna (Nitzsch) Ehrenberg (Fragilaria ulna (Nitzsch) Lange-Bertalot)

Bacillariophyceae Haeckel

Eunotiophycidae D. G. Mann

Eunotiales Silva

Eunotiaceae Kützing

6. Eunotia diodon Ehrenberg

Bacillariophyceae Haeckel

Cymbelalles D. G. Mann

Cymbellaceae Greville

7. Cymbella affinis Kützing

8. Cymbella excisa Kützing

9. Cymbella minuta Hilse

Gomphonemataceae Kützing

10. Gomphonema acuminatum Ehrenberg

11. Gomphonema olivaceum (Hornemann) Brébisson

12. Gomphonema gracile Ehrenberg

13. Gomphonema minutum (Agardh) Agardh

14. Gomphonema parvulum (Kützing) Kützing

15. Gomphonema truncatum Ehrenberg -
Achnanthales Silva

Achnantaceae Kützing

16. Achnanthes minutissima Kützing

Cocconeidaceae Kützing

17. Cocconeis placentula Ehrenberg

Naviculineae Hendey

Naviculaceae Kützing

18. Navicula capitatoradiata Germain

19. Navicula cryptocephala Kützing

20. Navicula radiosa Kützing

21. Navicula tripunctata Kützing

22. Navicula viridula (Kützing) Ehrenberg

Thalassiophysales D. G. Mann

Catenulaceae Mereschkowsky

23. Amphora ovalis (Kützing) Kützing

Bacilariales Hendey

Bacillariaceae Ehrenberg

24. Nitzschia dissipata (Kützing) Grunow

25. Nitzschia inconspicua Grunow

26. Nitzschia tubicola Grunow

27. Nitzschia palea (Kützing) W. Smith

Analyzing the samples we can say that the most taxa (90\%) are characterized as cosmopolitan (e.g., Diatoma vulgaris, Synedra ulna, , Cymbella affinis, Gomphonema parvulum, Achnanthes lanceolata, Cocconeis placentula,Navicula capitatoradiata, Amphora ovalis).

After laboratory work we can notice that the best represented family was Gomphonemataceae, and the best represented genus was Gomphonema with 6 specific taxa.
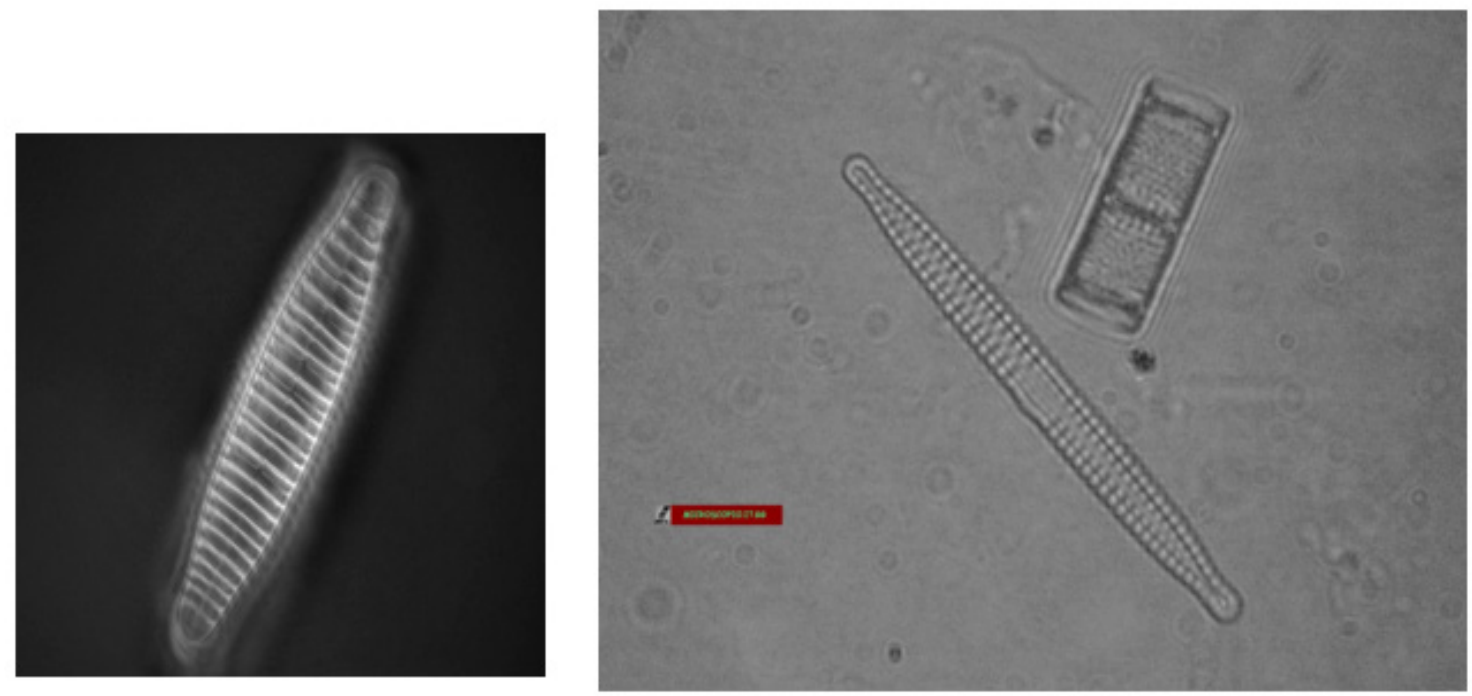

Fig. 2. Diatoma vulgaris (left) and Fragilaria capucina (right) 

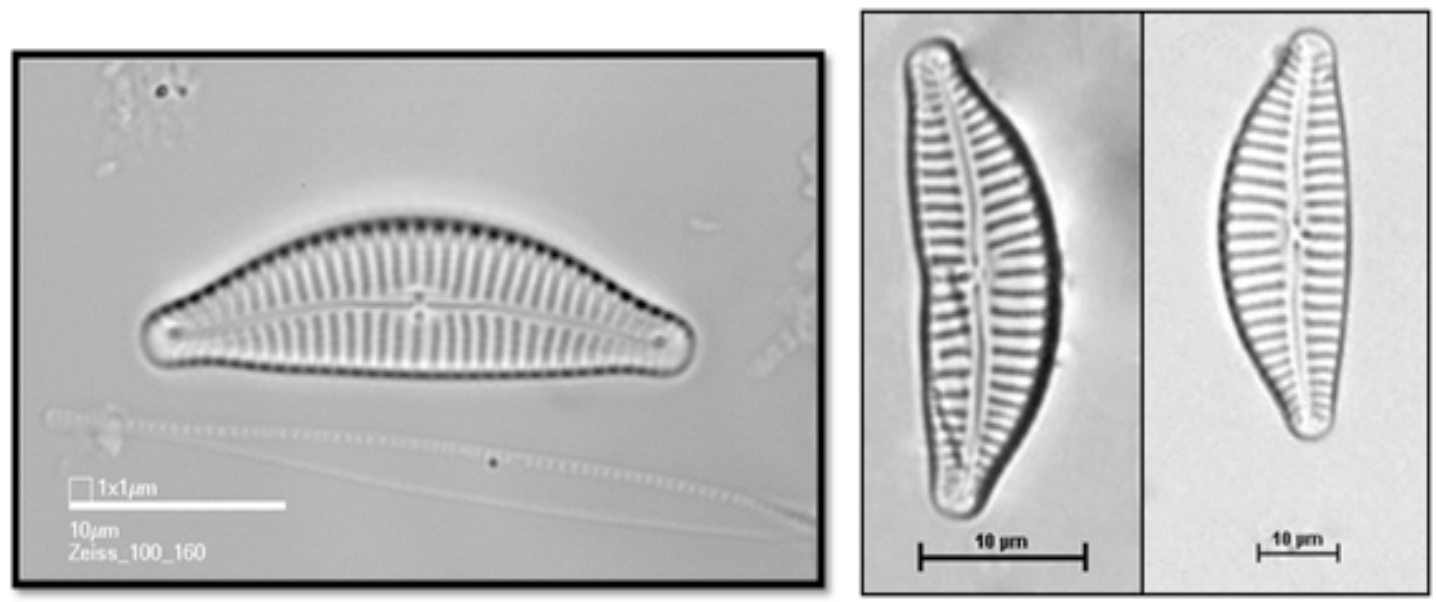

Fig. 3. Cymbella affinis (left) and Cymbella excisa (right)

From the saprobic categories circumscribing the identified taxa in the present study, the $\beta$ mesosaprobic category is prevailing (53\%).

\section{CONCLUSIONS}

Once the laboratory work was carried out, it was identified 26 species, distributed in 9 families, 6 orders and two classes, of the benthic diatoms from the Bega River until now. 53\% of the species identified are indicators of a good level of water.

Acknowledgments. On this way I want to thank my scientific mentor and all my collaborators for their support in achieving these experiments.

\section{REFERENCES}

1. Denys L, Verbruggen C (1989). Acause of drowning - the end of the Sublatanic peat growth and related palacoenvironmental changes in the lower Schedt Basin (Belgium) based on diatoms and pollen analysis, Rev Paleobot. Plynol. 59:7-36.

2. Krammer K, Lange-Bertalot H (1986), Bacillariophyceae: Naviculaceae. În Ettl, H., Gerloff, J., Heyning, H., Mollenhauer, D. (ed.), Susswasserflora von Mitteleuropa, vol. 2/1, G. Fischer, Stuttgart.

3. Krammer K Lange-Bertalot H (1988). Bacillariophyceae: Bacillariaceae, Epithemiaceae, Surirellaceae. În Ettl, H., Gerloff, J., Heyning, H., Mollenhauer, D. (ed.), Susswasserflora von Mitteleuropa, vol. 2/2, G. Fischer, Stuttgart.

4. Krammer K Lange-Bertalot H (1991a). Bacillariophyceae: Centrales, Fragilariaceae Eunotiaceae. În Ettl, H., Gerloff, J., Heyning, H., Mollenhauer, D. (ed.), Susswasserflora vo Mitteleuropa, vol. 2/3, G. Fischer, Stuttgart.

5. Krammer K, Lange-Bertalot H (1991b). Bacillariophyceae: Achnanthaceae. Kristisch Erganzungen zu Navicula
(Lineolatae) und Gomphonema. În Ettl, H., Gerloff, J., Heyning, H., Mollenhauer, D. (ed.), Susswasserflora von Mitteleuropa, vol. 2/4, G. Fischer, Stuttgart

6. Krammer K (2000). The genus Pinnularia. În LangeBertalot, H. (ed.), Diatoms of Europe - Diatoms of the European Inland Waters and Comparable Habitats, vol. 1, A.R.G. Gantner Verlag K.G., Ruggel.

7. Krammer K, Lange-Bertalot H (2000). Bacillariophyceae: English and French translation of the keys. În Budel, B., Gartner, G., Krienitz, L. Lokhorst, G. M. (ed.), Susswasserflora von Mitteleuropa, Vol. 2/5, G. Fischer, Stuttgart.

8. Krammer K (2002). Cymbella. În Lange-Bertalot, H. (ed.), Diatoms of Europe - Diatoms of the European Inland Waters and Comparable Habitats, vol. 3, Gantner Verlag K.G., Ruggel.

9. Krammer K (2003). Cymbopleura, Delicata, Navicymbulla, Gomphocymbellopsis, Afrocymbella. În Lange-Bertalot, H. (ed.), Diatoms of Europe - Diatoms of the European Inland Waters and Comparable Habitats, vol. 4, Gantner Verlag K.G., Ruggel.

10. Lange-Bertalot $H$ (2001). Navicula sensu stricto. 10 Genera Separated from Navicula sensu lato. Frustulia, În Lange-Bertalot, H. (ed.), Diatoms of Europe - Diatoms of the European Inland Waters and Comparable Habitats, vol. 2, Gantner Verlag K.G., Ruggel.

11. Lavoie I, Dillon PJ, Campeau S, (2009). The effect of excluding diatom taxa and reducing taxonomic resolution on multivariate analyses and stream bioassessment, Ecological Indicators, 9: 213-225.

12. Lixandru B (2006). Metodologie ecologică. Editura Eurobit, Timişoara.

13. Love RL (1974). Environmental requirements and pollution tolerance of freshwater diatoms EPA- 670/474-007.

14. Lowe RL, Pan Z (1996). Benthic Algal Communities as Biological Monitors. În Stevenson, R. J., Bothwell, M. L., Lowe, R. L., (ed.) Algal Ecology - Freshwater Benthic Ecosystems, Academic Press, San Diego: 705-739. 
15. Marin AA, Lixandru B, Petrovici M, Sinitean A, Morariu F, Popescu D (2014). Research regarding the diversity of the saprobionte categories in Bega river waters, Book of abstracts, 1.

16. Péterfi LŞ, Sinitean A (2002). Preliminary Studies on Diatoms in Thermo mineral Springs from Băile Herculane (Caraş - Severin District), Studies of Biodiversity, West Romania Protected Areas, USAMVBT: 25-28.

17. Petrovici M (2009). Evaluarea calității apei râului Crișul Repede utilizând larvele de efemeroptere (Insecta:
Ephemeroptera) ca bioindicatori), Editura Universității din Oradea

18. Ryu V, Lee JH, Yoo SB Gu XF, Moon YW, Jahng JW (2008). Sustained hyperphagia in adolescent rats that experienced neonatal maternal separation. Int. J. Obes. (Lond.) 32, 1355-1362 10.1038/ijo.2008.108

19. Round FE, Crawford RM, Mann DG, (2000). The Diatoms, Cambridge University Press, Cambridge: 1 - 747. 